\title{
The Development of Video Media on Measurement of Basic Quantities Mechanic
}

\author{
Yeni Megalina ${ }^{1}$, Sahyar $^{2}$,Juniar Hutahaean ${ }^{3}$ \\ \{yenimegalina@gmail.com, sahyarpasca@gmail.com, junhut@gmail.com
}

Physics Education Study Program FMIPA Unimed ${ }^{1,2,3}$

\begin{abstract}
This research is to develop a video media on measuring the basic quantities mechanics as well as valid length, practical and effective. The measuring instruments to be used include: vernier caliper, micrometer screw gauge, digital balance, three arms balance and digital stop watch. The media is expected to help students' skills both independently or with the help of lecturers in measuring the basic quantities mechanics. This research was conducted in the Unimed Physics Department.The type of research is research using the Research and Development (R \& D) method. The stages carried out during the research were tool needs analysis, media making design, media expert and media expert, revision, small group try out, revision, large group test, final revision. So the result of video media is found on lenght,mass of video media measuring length, mass and time measurement. In the teacher try out, small and large group try out, for extensive usage of this media will be uploaded on Line and you tube. The data analysis technique that used here is quantitative descriptive analysis technique that is by analyzing quantitative data obtained from expert test questionnaires and field tests. The results of the research show the basic quantities measuring mechanic video was valid, practical, and effective.(1) Precentage of assessment score from material experts 78,7 \% and percentage of assessment scores from media experts $81 \%$. So, Video as learning media included to valid criteria.(2) The practicality testing of the Video Learning was retrieved from questionnaire filling by the students. Results from the small group of students obtained $81 \%$. While the large group received $88.3 \%$.(3) The assessment Effectiveness as Learning Device based on the results of cognitive $82 \%$. Based on the results of the assessment and responses obtained from the questionnaire, it can be concluded that the video learning media for measuring the basic quantities Mechanics is suitable for used and developed.
\end{abstract}

Keywords: Measurement of basic quantities Mechanics, Line, you tube, quantitative data.

\section{Introduction}

Measurement is one of lecture materials in general physics courses. Many students have difficulty in understanding the material. From the data result of this study at Department of Physics of the State University of Medan is showing that many students obtain the minimum pass namely C. Only a few of students successfully obtain satisfactory grades namely A. This continued each year, just a little change even experienced a decrease. Besides general physics course is given for new students who unfamiliar with the activity of the lecture, it is a challenge for the lecturer to provide the appropriate learning materials and make student learn independently. 
General Physics course is 3 semester credit hours ( $\mathrm{SCH}$ ) consist of $2 \mathrm{SCH}$ for theory and $1 \mathrm{SCH}$ for practice. Practical work is carried out in the laboratory of physics but still not able to increase the motivation of students to learn independently and reduce the dependence of the presence of professors and their assistant. Another problem is the learning media which is not up to date. As we know, learning media is one of the factors determining the success of learning. Learning media is one of the devices to help professors delivering the message and the subject matter to students effectively and efficiently. Learning media usage in the process of teaching and learning can generate interest and desire, motivation and stimulation of learning activities, and even psychological influences brought against the student so that will help the effectiveness the learning process in the delivery of the message and the content. In addition to arousing the interest and motivation of students, learning media can also help students improve understanding, presenting data with interesting and condense information.

Video is one of audio visual media. There are many videos about length measuring instrument vernier caliper, mass measuring tool and time measuring tool. Although there is still no media showing the third measuring instrument simultaneously. In order to add students' interest and improve their understanding, video about this three measurement must be made and then uploaded to the LINE and You Tube. At this time, information technology is developing rapidly. It should be utilized in the process of learning. The utilization of information technology not only as a medium used directly in the classroom, but could also facilitate the students in studying independently. Currently, there are many internet features such as social media, games, blog, you tube and web site can be used as learning devices. According to Burnett \& Melisa (2008), You tube is a website in the form of popular video sharing service that allows to load and watch various video clips for free. In this case, the author will discuss about the usage of LINE and You tube as learning media for students.

The topic about media had been examined by a researcher Isma (2015). She concluded that the development of android-based chemistry learning aims to enhance learning motivation and cognitive achievement. And also, I Made, dkk (2014) found that the development of learning material in drawing with the software-aided Autocad application program can improve learning outcomes. According to Ika (2014) audio visual media/video influences the learning outcomes for Grade XI High School students in understanding the concept of elasticity. It can increase the motivation of learning and the cognitive achievement of HIGH SCHOOL students. Based on the the results of the findings above, the authors try to formulate this topic "The Development of video media on Measurement of Basic quantities Mechanic".

\section{Research methods}

This research is using Research and Development (R \& D) developed by R \& D Cycle Borg and Gall (1983). The steps of R \& D research according to the Borg and the Hall are :

a. Preliminary Studies by doing :

$\checkmark$ need analysis for length, mass and time measuring instruments;

$\checkmark$ theoritical studies;

$\checkmark$ the study of relevant research results, namely the library studies examine theory and research results that are relevant and the initial survey location research;

$\checkmark$ the initial survey for research location.

b. Research Planning by :

$\checkmark$ Formulating research objectives; 
$\checkmark$ Setting design and research stages.

c. Design development by determining:

$\checkmark$ Type of design;

$\checkmark$ Facilities;

$\checkmark$ Stages of the implementation of field trials;

$\checkmark$ Spesification of Task Description.

d. Field trials early stage involving material experts and media experts participation.

e. Doing revision of testing product, based on the feedback and suggestionfrom the initial field test results

f. Main field trial. Conduct trials on small scale or limited samples.

g. Test the revision of the product from the main field trials.

h. Operational field test. Test large scale, data collected through questionnaires, interviews, observations and others.

i. Completion of the final product, improvements were made based on the findings in the field implementation trial.

j. Dissemination andimplementation, to make the report of products at professional meeting and published in journals, working together between the publishers, monitor distribution to do quality control.

The data analysis techniques were carried out is using quantitative descriptive analysis techniques, namely by analyzing quantitative data in the form of figures obtained from expert test questionnaire and field test questionnaire. According to SuharsimiArikunto (1993: 27).quantitative data in the form of figures resulting from calculations or measurements are processed by adding up and then compared to the expected amount so that to obtain a percentage of feasibility. The formula that used is:

$$
P=\frac{X}{X i} \times 100 \%
$$

Where :

$\mathrm{P}=$ Percentage of each criteria

$\mathrm{X}=$ score of each criteria.

$\mathrm{Xi}=$ maximum score of each criteria

The main text should be written using Times New Roman, 10pt, fully justified. Italics can be used for emphasis and bold typeset should be avoided.

Table 1. Percentage table scale according to Suharsimiarikunto (1993: 2008).

\begin{tabular}{lll}
\hline Value & Criteria & Percentage \\
A & Very good & $80 \%<\mathrm{X}<100 \%$ \\
B & Good & $60 \%<\mathrm{X}<80 \%$ \\
C & Medium & $40 \%<\mathrm{X}<60 \%$ \\
D & Poor & $20 \%<\mathrm{X}<40 \%$ \\
E & Very poor & $0 \%<\mathrm{X}<20 \%$ \\
\hline
\end{tabular}

To test the effectiveness of video media measuring the principal amount of the Mechanics is obtained as follows: 


$$
x=\frac{\text { number of scores obtained }}{\text { ideal number of scores }} \times 100 \%
$$

Table 2. Assessment criteria

\begin{tabular}{lll}
\hline Value & Criteria & Percentage \\
A & Very good & $80 \%<\mathrm{X}<100 \%$ \\
B & Good & $60 \%<\mathrm{X}<80 \%$ \\
C & Medium & $40 \%<\mathrm{X}<60 \%$ \\
D & Poor & $20 \%<\mathrm{X}<40 \%$ \\
E & Very poor & $0 \%<\mathrm{X}<20 \%$ \\
\hline
\end{tabular}

Instrumen of data collection that used in this research is questionnaire evaluation forms. Questionnaire is a technique or method of collecting data indirectly. The instrument that used in this research was aimed to assessing the feasibility of video media measuring the principal amount of mechanics. The data that obtained from this questionnaire is quantitative data. The questionnaire form that used is a multilevel scale that is a question followed by columns that indicates the levels (SuharsimiArikunto, 1993: 125).

\section{Result of research and explanation}

\subsection{The result of research}

This research produces audio-visual media in form of basic quantitiesmesuring mechanics video learning. This video will be uploaded to LINE application for a small group of students especially the students majoring in physical education who has took participation in General Physics Course and also a large group of students especially the students majoring in physical education class $\mathrm{C}$ which are currently taking General Physics Course. As for the widespread use of this video learning, it will be uploaded via You Tube.

This research generates a product that is a valid, practical, effective and appropriate basic quantities measuring mechanics video.

\subsubsection{Review of material expert}

The material assessment covers two aspects of quality and material expediency. Data validation by the material expert can be seen in paragraph below:

The results of the expert assessment of this matter in terms of aspects (1) quality of material, obtained a score of $181(78 \%)$, and (2) the material expediency gained score 27 $(84.3 \%)$. Overall, the level of validation of learning material on video measurement magnitudes of principal mechanics earned score 208 (78.7\%). So the score of 208 from the material test, with the percentage of attainment of $78.7 \%$ are on a scale of 1 . The calculation results are presented in the table below: 
Tabel 3. The results of validation from material expert.

\begin{tabular}{llcl}
\hline $\begin{array}{l}\text { Valida } \\
\text { tion }\end{array}$ & $\begin{array}{l}\text { Aspects of } \\
\text { the } \\
\text { Validation }\end{array}$ & $\begin{array}{l}\text { The Results } \\
\text { of Valida- } \\
\text { tion }\end{array}$ & $\begin{array}{l}\text { Eligibility } \\
\text { Criteria }\end{array}$ \\
$\begin{array}{l}\text { Video } \\
\text { mate }\end{array}$ & $\begin{array}{l}\text { Quality } \\
\text { Expedienc }\end{array}$ & $78 \%$ & $\begin{array}{l}\text { Proper in } \\
\text { use "best in } \\
\text { predicate" }\end{array}$ \\
\hline
\end{tabular}

So this video media is valid. Based on the results of the analysis and evaluation of the expert, magnitudes measuring mechanic video needs some revisions. Their suggestions are:

$\checkmark$ Some images are out of focus;

$\checkmark \quad$ In measuring of depth shouldn't use a glass, it is better to use smaller objects;

$\checkmark$ The placement of the objects when measuring outer diameter with caliper is not precise;

The use of the caliper is less accurate.

\subsubsection{Review of media expert}

Validation by the media expert covers three aspects, namely the aspects of quality, language usage, the layout. The results of the media expert assessment of this matter in terms of aspects(1) the quality of the media gained a score of $44(84.6 \%)$, (2) use of language gota score of $19(79.2 \%)$, (3) the layout of the media obtained a score of $31(77.5 \%)$. Overall, the level of validation of learning material on tutorial video earned score $94(81 \%)$. So the score of 94 from the media test, with the percentage of attainment of $81 \%$ are on a scale of 1 . Note the table below:

Tabel 4. The result of validation from media

\begin{tabular}{|c|c|c|c|}
\hline $\begin{array}{l}\text { Validati } \\
\text { on }\end{array}$ & $\begin{array}{l}\text { Aspects of } \\
\text { the } \\
\text { Valida } \\
\text { tion }\end{array}$ & $\begin{array}{l}\text { The } \\
\text { Results of } \\
\text { Validation }\end{array}$ & $\begin{array}{l}\text { Eligibility } \\
\text { Criteria }\end{array}$ \\
\hline $\begin{array}{l}\text { Video } \\
\text { media }\end{array}$ & $\begin{array}{l}\text { Quality } \\
\text { Language } \\
\text { Usage } \\
\text { Layout }\end{array}$ & $\begin{array}{l}84.6 \% \\
79.2 \% \\
77.5 \%\end{array}$ & $\begin{array}{l}\text { Proper in } \\
\text { use } \\
\text { "best in } \\
\text { predicate" }\end{array}$ \\
\hline
\end{tabular}

In other words, these learning media from media aspect are valid . Based on the results of the analysis and evaluation of the media expert, magnitudes measuring mechanic video needs some revisions. Their advices on the video are:

$\checkmark$ We recommend the script (description) does not cover the measuring process;

$\checkmark$ We recommend that before shooting process, the cast doing rehearsal so it seems natural;

$\checkmark \quad$ The merging of multiple videos must be done precisely in order to produce smooth video.

The significationof measuring results by using caliperand screwmicrometers is less visible, this can lead confusion to the audience. 


\subsection{Headings, tables and figures}

Measurement is one of lecture materials in general physics courses. Many students have difficulty in understanding the material. From the data result of this study at Department of Physics of the State University of Medan is showing that many students obtain the minimum pass namely $\mathrm{C}$

\subsubsection{Response of student test results in a small group}

After getting suggestion from the experts, this video will be tested in a small groups consist of 8 students majoring in Physical Education who have participated in General Physics Course class before. Each of them was asked to view the videothrough LINE application, then they were asked to fill out aquestionnaire form. The form consists of 15 questions about three aspects : video display, video content, and its useability. The results of the questionnaireare : (1) the display, obtained the score $228(85,1 \%)$, (2) the content, received the score $84(81 \%)$,

(3) the usability, obtained the score $106(83 \%)$. Total overall score was $418(82 . \%)$. There are some inputs from the students about this magnitudes measuring mechanic video. Their inputs are:

$\checkmark \quad$ To avoid the lost of some video parts, video must be edited delicately;

$\checkmark$ The explanation in video content should be delivered more slowly;

$\checkmark$ Use a brief note;

$\checkmark$ The video volume must be made louder.

\subsubsection{Response of student test results in larger group}

After a series of validation and revision, thetutorial video was tested to the students of Physical Education Class C. The testing subject consisted of 40 students. The researchers asked the students to open LINE application on their android and watched it. Next, the students are requested to provide a response by filling out the questionnaire form. The form consists of 15 questions about three aspects : video display, video content, and its useability. The results of the questionnaire are : (1) the display, obtained the score $1191(84.2 \%)$, (2) the content, received the score $259(84 \%)$, (3) the usability, obtained the score $558(88.3 \%)$. Total overall score was $2008(85,4 \%)$. There are some inputs from the students about this magnitudes measuring mechanic video. Their inputs are:

$\checkmark \quad$ The material description should be made in detailed explanation;

$\checkmark \quad$ The video volume must be made louder;

$\checkmark \quad$ The video timeshould be made shortened;

$\checkmark$ Use a brief/simple note;

$\checkmark \quad$ Use appropriate music background;

$\checkmark \quad$ The Note color should be made contrast to the layout;

$\checkmark$ The presenter must be exposed in video;

$\checkmark$ The video should be uploaded to the other social media such asWhatsapp, BBM, Instagram, etc.

Based on the research that has been done on the results ofThe developmentof video media on Measurement of Basic quantities Mechanics, found that the score of student learning outcomes from 40 responden in the range 10-17. From the calculations show that the lowest 
score of 10 and the highest score of 17 .The value of the effectiveness of video media is $82 \%$ belongs to the very good category.

\subsection{Explanation}

The results of the research show the basic quantities measuring mechanic video was valid, practical, and effective.

1. Validity of The Video as Learning Mediaachievement is $81 \%$ and $77.8 \%$ for media expBased on material experts validation, the percentage of erts assessment. Thus, Video as learning media included to VALID criteria.

2. Practicality of The Video LearningThe practicality testing of the Video Learning was retrieved from questionnaire filling by the students. The practicality usage of LINE application is also being asked. Results from the small group of students obtained $80 \%$. While the large group received $88.3 \%$.

3. Effectiveness as Learning Device. The assessment effectiveness as learning device based on the results of cognitive $82 \%$.

\section{Conclusions and suggestions}

Based on the results of the research can be concluded that magnitudes measuring mechanic video learning are valid, practical, effective and very decent used, with details:

(1) Valid, the assessment of the material and media experts already ensure this criteria;

(2) Practical, the using of LINE application to play the video learning get very good responses from the students in small group and also larger group;

(3) Effective, It is called effective because it supports learning process;

There are also some suggestions for this video learning :

(1) The video duration should be made shortened because it can make students and the audience get bored.

(2) Advanced research needed to be done similar to this research. 


\section{References}

[1]Arsyad,Azhar.(2014).MediaPembelajaran.Jakarta:RajagrafindoPersada.

[2]Dwi, Florentina Astuti., Sutrisno, Leo.,dan Maria,Haratua Tiur. Remediasi Menggunakan Multi-Representasi Untuk Mengurangi Siswa Sma Yang Tidak Dapat Menyelesaikan Soal Hukum Archimedes. Program Studi Pendidikan Fisika FKIP Untan Pontianak.

[3]Efendi, Anwar ., Sumarni, Sri., dan Efendi, Agus.Pengembangan Media Pembelajaran Berbasis Video Tutorial Pada Mata Kuliah Mekanika Tanah.Program Studi Pendidikan Teknik Bangunan FKIP UNS

[4]Halliday dan Resnick.(1991). Fisika Jilid 1.Jakarta :Erlangga

[5]Hamalik, Oemar. (2008). Kurikulum dan Pembelajaran. Jakarta :Bumi Aksara.Sardiman, Arief .(2008).Media Pendidikan. Jakarta:Rajawali.

[6]Hamalik, Oemar. (1994). Media Pendidikan. Cetakan ke-7.Bandung:Citra Aditya Bakti.

[7]Harahap, Lola Wita., \& Surya, Edy. (2015). Development of Learning Media in Mathematics for Student with Special Needs. International Journal of Sciences : Basic and Applied Research (IJSBAR), 33(3),1-12.

[8]Jatmika, Herka Maya. (2005). Menunjang Pembelajaran Pendidikan Jasmani di Sekolah Dasar.Jurnal Pendidikan Jasmani Indonesia.Volume 3 No. 1 (89-100).

[9]Kanginan, Marthen.(2007).Fisika kelas untuk kelas X SMA.Jakarta :Erlangga.

[10]Kominfo.com, 2015. Pengguna Internet di Indonesia 63 Juta Orang. http://kominfo.go.id/index.php/content/detail/3415/Kominfo+\%3A+Pengguna+Internet+di +Indonesia+63+Juta+Orang/0/berita_satker. Diakses tanggal 13 Maret 2015

[11]Kusuma, Dwi Hendra.,Wahyuni, Sri ., dan Noviani, Leny. Pengembangan Media Pembelajaran Video Tutorial Untuk Meningkatkan Hasil Belajar Siswa Pada Mata Pelajaran Pemasaran Online Di SMK Negeri 3 Surakarta.Pendidikan Ekonomi, FKIP Universitas Sebelas Maret.

[12]Lubis R.I.,dan Ikhsan Jaslin .(2015). Pengembangan Media Pembelajaran Kimia Berbasis Android Untuk Meningkatkan Motivasi Belajar dan Prestasi Kognitif Peserta Didik SMA.Volume 1-Nomor 2, (191-201).

[13]Pramudito, Aria. (2013). Pengembangan Media Pembelajaran Video Tutorial Pada Mata Pelajaran Kompetensi Melakukan Pekerjaan dengan Mesin Bubut di SMK Muhammadiyah 1 Playen .Universitas Yogyakarta.

[14]Primavera Citra R.I. (2014). Pengaruh Media Audio Visual (video) Terhadap Hasil Belajar Siswa kelas XI Peserta Didik SMA Konsep Elastisitas. Prosiding Seminar Nasional Pendidikan IPA FITK UIN Syarif Hidayatullah Jakarta.

[15]Sani,A.R.,Manurung,R.S.,Suswanto,H.,Sudiran.(2018). Penelitian Pendidikan. Jakarta:Tira Smart.

[16]Sanjaya, W. (2012). Media Komunikasi Pembelajaran.Jakarta: Kencana Prenada Media Group.

[17]Sanaky,Hujair AH.(2009). Media Pembelajaran. Yogyakarta: SafiriaInsania Press.

[18]Sari S.D., SugiyartoH.K .(2015).Pengembangan multimedia berbasis masalah untuk meningkatkan motivasi belajar dan kemampuan berpikir kritis siswa.Jurnal inovasi Pendidikan Fisika. Volume 1 Nomor 2, Oktober 2015 ( 153-166).

[19]Sanaky,Hujair AH.(2009). Media Pembelajaran. Yogyakarta: Safiria Insania Press. [20]Sudjana, Nana dan Ahmad Rivai.(2013).Media Pengajaran. Bandung:Sinar Baru Algensindo. 
[21]Soma I Made,.Candisa I Made,. Dan TegehI Made. (2014). Pengembangan Bahan Ajar Menggambar Dengan Perangkat Lunak BerbantuanProgram Aplikasi Autocad.e- Journal Program Pascasarjana Universitas Pendidikan Ganesha. Volume 4 tahun 2014 .

[22]Sudjana,Nana. (2013). Dasar-dasar Proses Belajar Mengajar. Bandung:Sinar Baru Algensindo.

[23]Arikunto, Suharsimi .(1993). Prosedur Penelitian Suatu Pendekatan Praktik (edisi revisi II, Cetakan Kesembilan). Jakarta: Penerbit Rineka Cipta.

[24]Susanto, Ahmad. (2014). Teori Belajar dan Pembelajaran di Sekolah Dasar. Jakarta:Kencana Prenada Media Group.

[25]Vidya, P., \& Manivannan, C. (2010). Development of an educational interaktive videoDVD $\mathrm{n}$ dairy health management practices. International Journal of Education and Development using Information and Communication Technology (IJEDICT), 6(1), 30-39.

[26]Yoshida, Hiroki. (2010). Development and formative evaluation of the "Educational Media In- Service Teacher Training Curriculum Standards". International Journal of Education and Development using Information and Communication Technology (IJEDICT), 6(3), 37-55.

[27]Young,H.D dan Freedman.(2004). Fisika Universitas Jilid 1. Jakarta: Erlangga 